PRZEGLĄD NAUK HISTORYCZNYCH 2017, R. XVI, NR 2

http://dx.doi.org/10.18778/1644-857X.16.02.02

Matgorzata KaRKocha

UNIWERSYTET ŁÓDZKI

\title{
Wojna rosyjsko-turecka (kampania 1789 roku) w świetle doniesień „Pamiętnika Historyczno- -Polityczno-Ekonomicznego"
}

Streszczenie. Przedmiotem artykułu jest wojna rosyjsko-turecka $z$ lat 17871792, a ściślej rzecz ujmujac - kampania roku 1789. Zagadnienie to zostanie omówione na podstawie informacji publikowanych na łamach „Pamiętnika Historyczno-Polityczno-Ekonomicznego”. Pismo to ukazywało się w Warszawie w latach 1782-1792, a jego redaktorem i wydawca był ksiądz Piotr Świtkowski. Od początku wojny rosyjsko-tureckiej, do której w lutym 1788 r. przyłączyła się Austria jako sojusznik Katarzyny II, „Pamiętnik” zamieszczał periodyczne sprawozdania $z$ działań na froncie tureckim. Opisywał najważniejsze bitwy, ale też mało istotne potyczki, informował o ruchach i stanie walczacych armii, drukował etaty wojsk i wiadomości biograficzne o dowódcach. Świtkowski był zwolennikiem polityki protureckiej i jako taki z sympatia wypowiadał się na temat Porty i jej mieszkańców, chwalił waleczność tureckiego żołnierza, pozytywnie odnosił się też do reform wojskowych przeprowadzanych w tym państwie.

Słowa kluczowe: wojna rosyjsko turecka 1787-1792, kampania 1789 roku, „Pamiętnik Historyczno-Polityczno-Ekonomiczny”, Piotr Świtkowski, prasa warszawska, XVIII wiek.

\section{amiętnik Historyczno-Polityczno-Ekonomiczny" był miesięcz- nikiem redagowanym przez eksjezuitę, księdza Piotra Świtkow- skiego (1744-1793) ${ }^{1}$. Pismo ukazywało się w latach 1782-1792}

*Wydział Filozoficzno-Historyczny, Instytut Historii, Katedra Historii Nowożytnej, e-mail: malkarkocha@o2.pl.

${ }^{1}$ Na temat życia oraz działalności pisarskiej i wydawniczej Świtkowskiego por. E. Aleks androwska, Świtkowski Piotr, [w:] Dawni pisarze polscy od poczatków piśmiennictwa do Młodej Polski. Przewodnik biograficzny i bibliograficzny, t. IV (S-T), koordynacja całości R. Loth, Warszawa 2003, s. 232-233; I. Łos s ow s ka, 
w stolicy Rzeczypospolitej pod kilkakrotnie zmienianym tytułem: w 1782 i 1783 r. jako „Pamiętnik Polityczny i Historyczny, dziejów, ustaw, osób, miejsc i pism wiek nasz szczególniej interesujących”, od 1784 r. jako „Pamiętnik Historyczno-Polityczny przypadków, ustaw, osób, miejsc i pism wiek nasz szczególniej interesujacych”, a od roku 1788 pod nazwa "Pamiętnik Historyczno-Polityczno-Ekonomiczny przypadków, ustaw, osób, miejsc i pism wiek nasz szczególniej interesujacych”. Gazeta odbijana była w drukarni Jego Królewskiej Mości w niewielkim formacie in $16^{\circ}$. Objętość każdego zeszytu wynosiła ok. 80 stron, a w okresie Sejmu Czteroletniego przekraczała nawet 100 stron. „Pamiętnik” był czasopismem o charakterze ekonomiczno-społecznym, niemniej na jego łamach zamieszczano także zbiór informacji o najnowszych wydarzeniach na świecie ${ }^{2}$.

Układ poszczególnych numerów był w zasadzie stały. Pierwszy artykuł stanowił wypis $z$ podróży zagranicznych, następnie drukowano relacje o życiu wybitnych mężów stanu i wodzów, zaczerpnięte $z$ dzieł obcojęzycznych. Dalej następował przegląd zagranicznych wydarzeń politycznych: omawiano przebieg konfliktów zbrojnych, układ sił wewnętrznych w państwach, posunięcia dyplomatyczne monarchów. Kolejne artykuły sięgały do zagadnień polskich, a wiele $z$ nich dotyczyło handlu, przemysłu i rolnictwa. W stałym dziale pt. Obraz polityczny różnych krajów (także Dzieje różnych krajów i Obraz polityczny Europy) znajdowały się aktualne informacje z zagranicy, a niekiedy również z kraju. Od 1787 r. na końcu każdego numeru, jeśli pozwalało na to miejsce, Świtkowski zamieszczał dział Nowe wynalazki, piękne kunszta. Informowano w nich o najnowszych osiagnięciach naukowych, smierci wybitnych uczonych, poczynaniach władców w kwestii przyspieszenia rozwoju handlu i rolnictwa, podniesienia poziomu oświaty, a także podawano szereg praktycznych rad.

Piotr Świtkowski (1744-1793), [w:] Pisarze polskiego Oświecenia, red. T. Kostkiewiczowa, Z. Goliński, t. II, Warszawa 1994, s. 305-319; I. H o m ol a-D zi k o w s k a, Pamiętnik Historyczno-Polityczny Piotra Świtkowskiego 1782-1792, Kraków 1960, s. 10-24.

2 Stało się to powodem prześladowania Świtkowskiego przez księdza Stefana Łuskinę, redaktora „Gazety Warszawskiej”, który prowadził z nim zacięta polemikę, a nawet wytoczył mu proces o naruszenie monopolu na wydawanie gazet informacyjnych w stolicy. Szczegółowo na ten temat por. J. Łojek, „Gazeta Warszawska" księdza Łuskiny (1774-1793), Warszawa 1959, s. 75-79; J. B a r t o s z ewicz, Gazeta księdza Łuskiny, [w:] id e m, Znakomici mężowie Polscy w XVIII w., t. I, Petersburg 1855, s. 304-309. 
Doniesienia polityczne z zagranicy publikowane w „Pamiętniku” były obszernymi wyciagami z czasopism obcych. Świtkowski korzystał głównie $z$ gazet francuskich, włoskich, angielskich i zwłaszcza niemieckich, językiem tym władał bowiem biegle. Wśród prenumerowanych przez niego pism znajdowały się m.in. "Mercure de France”, „Journal de Paris”, tzw. „Gazeta Hamburska” (,Staats und Gelehrte Zeitung des Hamburgischen Unpartheyischen Correspondenten”) oraz „Dziennik Uczony Altoński”. Potrzebne wiadomości redaktor tłumaczył sam lub zlecał komuś innemu, a następnie zamieszczał w „Pamiętniku”. Drukował również obszerne wypisy $z$ książek zagranicznych i pism ekonomistów niemieckich (m.in. Schubarta), a także prace nadsyłane doraźnie przez czytelników, $z$ których część miała formę tzw. listów do redakcji³.

Od poczatku wybuchu wojny rosyjsko-tureckiej Świtkowski zamieszczał na łamach redagowanego przez siebie pisma miesięczne artykuły omawiajace przebieg tego konfliktu ${ }^{4}$. Informował o działaniach na lacdzie i morzu, o ruchach i stanie nieprzyjacielskich armii, opisywał najważniejsze bitwy i mało istotne potyczki, drukował etaty wojsk, przytaczał wiadomości statystyczne, geograficzne i biograficzne. Donosił nadto o zabiegach podejmowanych przez dwory europejskie na rzecz przywrócenia pokoju. Dodać należy, że redaktor „Pamiętnika” był zwolennikiem orientacji protureckiej, co nie pozostało bez wpływu na treść przekazywanych informacji. Z sympatią wypowiadał się na temat Turcji i Turków, chwalił odwagę i bitność żołnierzy osmańskich, starał się również wykazać, że Wysoka Porta nie jest bynajmniej tak bardzo „przeżarta” wewnętrznym rozkładem, jak powszechnie sądzono ${ }^{5}$.

${ }^{3}$ Więcej na temat tego pisma por. I. Homola-Dzikowska, op. cit., passim; oraz W. Giełżyński, Prasa warszawska 1661-1914, Warszawa 1962, s. 45-50; M. Karkocha, Obraz Francji $w$ dobie rewolucji na łamach prasy warszawskiej z lat 1789-1794, Łódź 2011, s. 51-62; J. Łoj ek, Historia prasy polskiej, Warszawa 1976, s. 50-52; i d e m, Dziennikarze i prasa $w$ Warszawie $w$ XVIII wieku, Warszawa 1960 , s. 94 i n.

${ }^{4}$ Pisał o tym nieraz także w dziale Obraz polityczny różnych krajów.

${ }^{5}$ Na przykład w lipcu 1788 r., porównując siły wojskowe Turcji i sprzymierzonych dworów cesarskich, ksiądz redaktor pisał: „Aż do zaczęcia niniejszej wojny mniemania o wojsku tureckim były opaczne i prawie fałszywe. Pisma publiczne wystawiały wojsko tureckie jako gromadę niezliczoną ludzi miękkich, niekarnych, bezbronnych, którzy nie czynią ani karności, ani ćwiczenia wojennego, ani znajomości tego kunsztu. Obiecywano, że jak się prędko w kupę zebrali, tak jeszcze prędzej za poniesieniem pierwszej jakiej klęski lub doznaniem głodu, niewczasu i trudów wojennych mieli się rozsypać i odbiec choragwi Mahometa. Mniemania 
Wojna między Imperium Rosyjskim a Imperium Osmańskim rozpoczęła się w sierpniu $1787 \mathrm{r}$. Bezpośrednim powodem zerwania stosunków dyplomatycznych między obu państwami było spotkanie imperatorowej Wszechrosji z Józefem II w Chersoniu w maju tego roku, co gabinet turecki potraktował jako prowokację. Naprawdę chodziło jednak o aneksję Krymu (1783 r.) i objęcie przez Katarzynę II protektoratu nad wschodnią Gruzja, a także inne kwestie mniejszej wagi ${ }^{6}$, stojące $\mathrm{w}$ jawnej sprzeczności $z$ postanowieniami traktatu w Küczük Kajnardży (1774 r.). Turcy wystawili olbrzymia, licząca ponad 200000 żołnierzy armię pod wodzą wielkiego wezyra Kodża Jusuf Paszy. Wysłali też na Morze Czarne większość swojej floty, dowodzonej przez kapudana paszę Gazi Hasana. Planowano atak z Oczakowa na Kinburn, Chersoń i Krym. Rosja, zaskoczona rozwojem wypadków, była do wojny nieprzygotowana. Upłynęło kilka miesięcy, nim jej wojska (120 000 żołnierzy) mogły zebrać się na południu kraju. Rosyjskie siły zbrojne podzielone były na dwie armie: Ukraińska pod wodza hrabiego Piotr Rumiancewa Zadunajskiego, weterana poprzedniej wojny tureckiej, i Jekatierynowska pod dowództwem księcia Grigorija Potiomkina, $z$ woli monarchini pełniącego funkcje marszałka polowego i wielkiego admirała. W dyspozycji pozostawały pułki stacjonujace na Kaukazie i Kuba-

te wspierały się na stanie rzeczy przeszłych czasów. Lecz to odmieniło się. [...] Turcy, słowa sa jednego Angielczyka, który wiele lat strawiwszy w Konstantynopolu, świeżo stamtąd powrócił, nie są podczas niniejszej wojny w złym stanie, jak wielu trzyma błędnie. Ich straże dotrzymują miejsc swoich $z$ większa dokładnościa, ich pikiety bywają rozstawiane $z$ roztropnością i ostrożnością wojenna, a ich patrole chodza tak regularnie, jak w innym jakim europejskim wojsku. Teraz nie można na nich tak łatwo zasadzać łapek, jak podczas przeszłej wojny. Artyleria, która przedtem składała się z sztuk ogromnych i do przeprowadzenia trudnych, jest teraz lekka i lepiej urządzona, podług miary francuskiej i angielskiej”. I dalej: „Turecka jazda uwija się z niewymowna szybkością, nie daje nigdy pokoju nieprzyjacielowi, napada na jego straże i dokucza mu bez ustanku. Infanteria turecka jest także teraz lepiej wyćwiczona niż przedtem [...]”. „Pamiętnik Historyczno-Polityczno-Ekonomiczny" [dalej: PHPE], lipiec 1788, s. 592-595.

${ }^{6}$ Udzielenie schronienia księciu multańskiemu Aleksandrowi; utrudnianie mieszkańcom Oczakowa wydobycia soli z jezior położonych między Kinburnem a Kobkoi, do czego $z$ dawna mieli prawo; podburzanie przeciwko Turcji jej poddanych w Multanach, Wołoszczyźnie i na archipelagu wysp greckich; stosowanie restrykcji wobec kupców tureckich na terenie Rosji i inne. Wszystkie zażalenia i kwestie sporne zostały wyłuszczone w manifeście Porty z sierpnia 1787 r., przedłożonym ministrom zagranicznych dworów w Konstantynopolu. Ksiądz redaktor wspomniał o nim w „Pamiętniku”, nie podał jednak jego treści. Został on przedrukowany w całości przez konkurencyjna wobec pisma Świtkowskiego „Gazetę Warszawska” (nr 41-43 z 1788 r., bez paginy). 
niu, komenderowane przez generała Tökelego. Głównym zadaniem wojsk rosyjskich było opanowanie fortec nadmorskich, od Oczakowa aż do ujścia Dunaju, a tym samym połączenie Półwyspu Krymskiego, Nowej Rosji i Besarabii.

Turcy jeszcze w 1787 r. usiłowali zająć Kinburn, lecz bez większego powodzenia. Ich flota, dwukrotnie pobita na wodach limanu dnieprowego i pod Oczakowem (18 i 28 czerwca 1788 r.), jak również koło wyspy Fidonisi na wschód od delty Dunaju (14 lipca 1788 r.), wycofała się do Konstantynopola. Na lądzie wielki wezyr wzbraniał się przed wydaniem walnej bitwy nieprzyjacielowi, zadowalając się wysyłaniem w teren licznych podjazdów. W lutym 1788 r. cesarz Józef II, wypełniając zobowiązania sojusznicze wobec Katarzyny II, wypowiedział Porcie wojnę. Austriakom nie udało się odnieść zdecydowanego zwycięstwa, mimo to zdobyli Chocim w Mołdawii i kilka mniejszych twierdz na terenie Bośni (Dreśnik, Dubica, Novi) i Serbii (Sabacz). Rosjanie prowadzili działania dość niemrawo. Głównym ich sukcesem było zajęcie twierdzy Oczaków nad Morzem Czarnym, wziętej gwałtownym szturmem po wielotygodniowym oblężeniu (17 grudnia 1788 r.) $)^{7}$. Switkowski szeroko rozpisywał się na temat tego wydarzenia w lutowym numerze „Pamiętnika”, wskazujac na okrucieństwo wojsk imperatorowej, które wycięły w pień całą bez mała ludność cywilną.

W maju 1789 r. ksiądz redaktor poinformował o otwarciu nowej kampanii na froncie wschodnim, opisał przygotowania zbrojne Porty oraz pierwsze potyczki i akcje. Turcy tego roku pojawili się w polu znacznie wcześniej niż w roku poprzednim, zmobilizowali do walki całe siły wielomilionowego państwa. W zimie 1788/1789 r. ze wszystkich stron Azji ściągnęły do Konstantynopola liczne wojska, znacznie liczniejsze, niż się spodziewano. Pasza Kara Osman Oglu i pasza Armenii miast wystawić 8000 ludzi, których żądał

7 Szerzej o początkach wojny i kampanii 1788 r. por. W. Kalinka, Sejm Czteroletni, t. I, Warszawa 1991, s. 28-45; W. Morawski, S. Szawłowska, Wojny rosyjsko-tureckie od XVII do XX wieku, Warszawa 2006, s. 80-86; J. Gozdawa-Gołębiowski, Wojny morskie 1775-1851, Warszawa 2001, s. 137-142; P.P. Wieczorkiewicz, Historia wojen morskich. Wiek żagla, t. I, Warszawa 1995, s. 406-410; a zwłaszcza M. Karko cha, Wojna rosyjsko-turecka na łamach "Pamiętnika Historyczno-Politycznego" (1787-1788), [w:] Sic erat in votis. Europa $i$ świat $w$ czasach nowożytnych. Studia i szkice ofiarowane Profesorowi Zbigniewowi Anusikowi w sześćdziesiąta rocznice urodzin, red. M. Karkocha, P. Robak, Łódź 2017, s. 311-342.

8 PHPE, luty 1789, s. 137-155. 
Dywan, zebrali armię w sile 48000 żołnierzy. Nadzieja wielkich łupów sprawiła, że Azjaci tłumnie i $z$ wielkim entuzjazmem zaciągali się pod sztandary Mahometa. Odbudowana została także flota turecka: składała się $z$ ok. 200 mniejszych i większych jednostek pływajacych ${ }^{9}$. Wielki admirał (kapudan pasza) Gazi Hassan zamierzał wziąc na okręty 24000 żołnierzy w celu odnowienia siły otomańskiej nadwyrężonej nieco w ubiegłej kampanii. Utrzymanie tak licznych wojsk lądowych i morskich wymagało, rzec jasna, odpowiednich nakładów finansowych. Dywan nakazał więc poddanym w Europie wszystkie srebrne sprzęty, naczynia i ozdoby oddać do mennicy, gdzie miały być przetopione na pieniądze ${ }^{10}$. Gazi Hassan był jednym $z$ pierwszych, którzy wykonali to polecenie, a wielki wezyr Kodża Jusuf Pasza zostawił sobie tylko dwa bogate rzędy. Ten ostatni, jako naczelny wódz armii tureckiej, wydał rozkaz zgromadzenia wojsk na terenie Wołoszczyzny, Besarabii, Serbii i Bośni. Jeszcze w marcu i kwietniu 1789 r. liczne oddziały tureckie $z$ Wołoszczyzny robiły wypady do Siedmiogrodu, lecz były przez żołnierzy cesarskich za każdym razem odpędzane. Jedna taka grupa dotarła do Ocna, położyła trupem kilkunastu ochotników, miasteczko złupiła i spaliła, a wracając, uczyniła to samo z leżącymi po drodze miejscowościami ${ }^{11}$.

Świtkowski pisał dalej, że wojenne czynności i przygotowania Turcji korelowały $z$ żądaniami, jakie przedstawiła ona cesarzowi za pośrednictwem posła hiszpańskiego, usilnie pracującego nad przywróceniem pokoju w Europie. Porta domagała się zwrotu wszystkich ziem i fortec, utraconych w czasie tego konfliktu, nadto Banatu jako rekompensaty poniesionych kosztów wojennych. Dwór wiedeński odpowiedział na to, że ponieważ sułtan nie jest skłonny do poniesienia żadnych ofiar, przeto nie dostanie nic i wojna trwać będzie do dalszego rozstrzygnięcia. Owa nota cesarska, wysłana do Konstantynopola jeszcze 17 marca, sprawiła wielkie poruszenie w wojsku austriackim i wzbudziła w żołnierzach chęć do natychmiastowej walki. Jednak $z$ powodu wielkich powodzi armia Józefa II nie mogła rozpocząć działań wojennych i stanąć obozem aż do po-

${ }^{9}$ W poprzedniej kampanii turecka flota wojenna liczyła 80 różnych okrętów. Por. PHPE, marzec 1788, s. 237.

10 Za każde oka srebra, tj. niespełna 3 funty, płacono w mennicy 100 piastrów. „Lecz że piastr turecki - pisała Świtkowski - ledwie ma połowę srebra i wartości wewnętrznej, która oznacza, zyskuje Porta na tej operacji około 60 procentu". PHPE, maj 1789, s. 503-504.

11 Ibidem, s. 501-505. 
czątku maja 1789 r. Inną bolączka, z jaka armia ta borykała się w tym czasie, była epidemia. Mór zebrał największe żniwo w korpusie słowackim, gdzie w lutym zmarło 1090 żołnierzy infanterii i 79 kawalerii. W chorwackich lazaretach pod koniec tego miesiąca przebywało 5619 chorych, całe zaś wojsko chorwackie liczyło wówczas nieco ponad 35 000. Zatem piąta część armii była niezdolna do walki. Wielkie rekrutowanie w krajach austriackich wynagrodziło tę stratę, tak że na początku maja wszystkie regimenty były już na nowo skompletowane. Do armii zgłaszali się głównie ochotnicy z Węgier, w kraju tym panowała bowiem drożyzna i wielu ludzi nie miało źródła utrzymania ${ }^{12}$.

Wylewy Dunaju i Sawy, a przede wszystkim ciężka choroba cesarza opóźniły otwarcie kampanii po stronie austriackiej. Feldmarszałek Andreas Hadik von Futak ${ }^{13}$ dopiero w maju wyruszył do głównej armii w Syrmii (Srem), aby objąć najwyższą komendę na miejsce Josepha Franza hrabiego von Lascy (sive Lacy) ${ }^{14}$. W pole wyruszył także feldmarszałek Ernst Gideon baron von Laudon (Loudon) ${ }^{15}$, który na czele 80-tysięcznego wojska zamierzał podbić turecka Chorwację i Bośnię. Osmanie, korzystając ze zwłoki nieprzyjaciela, w różnych miejscach próbowali wedrzeć się na teren państwa Józefa II. Pierwsza znaczniejsza napaść ze strony tureckiej nastapiła w Chorwacji przy Szlaku Likańskim. „Mogłaby się ona stać szkodliwa dla [żołnierzy] cesarskich - czytamy w „Pamiętniku” - tylko znak dany od Turków przez trojakie wystrzelenie $z$ harmat, dał poznać Austriakom ich zamysł, przez co się prędko zebrali i byli w stanie odparcia Turków ze strata" ${ }^{16}$. Podobnie nie udał się oddziałom osmańskim drugi napad w tych stronach pod Przytynem. Inna akcja - 8 kwietnia w Transylwanii - była znacznie ważniejsza, choć dla Porty także niepomyślna. Tego dnia 7000 jazdy i piechoty tureckiej zbliżyło się pod Valli Muliri na granicy Transylwanii i spędziwszy stamtąd 200 strzelców austriackich, pomknęli aż do Dicalu Hontili, gdzie wspomniani strzelcy uszykowali się do walki, odebrawszy pomoc złożona z kilku szwadronów huzarów i pięciu dywizji infanterii. Żołnierze cesarscy stanęli w takim miejscu, że niepodobna było

\footnotetext{
12 Ibidem, s. 505-507.

${ }^{13}$ Por. C. von Wurzbach, Biographisches Lexikon des Kaiserthums Oesterreich, T. XIV, Wien 1865, s. 166-170.

${ }^{14}$ Por. J. Hirtenfeld, Der Militär-Maria-Theresien-Orden und seine Mitglieder: Nach authentischen quellin bearbeitet, Wien 1857, s. 60-62.

15 Por. ibidem, s. 48-57; C. von Wurzbach, op. cit., T. XVI, Wien 1867, s. 66-92.

16 PHPE, maj 1789, s. 508.
} 
do nich przystapić, jak tylko przez ciasny wąwóz, broniony przez strzelców i zręcznie rozstawione armaty. Jazda turecka $z$ wielką odwaga przedarła się przez niego i zaczęła atakować Austriaków, nie mogac jednak nic zrobić przeciwko artylerii, wspartej liczna jazdą i piechotą. Po trzygodzinnym natarciu musiała się wycofać, zostawiwszy na placu boju 253 żołnierzy. Straty austriackie były niewielkie - kilkunastu rannych i zabitych ${ }^{17}$.

Wielki wezyr widząc, że jego podjazdom zanadto nie szczęściło się na tych terenach, nakazał seraskierowi Anatolii Haggy Soitary, dowodzącemu znacznym korpusem kawalerii na Wołoszczyźnie, aby postapił bliżej wojsk księcia Federicka Josepha von Sachsen-Coburg-Saalfeld ${ }^{18}$, rozłożonego obozem pod Roman w Multanach. Dnia 19 kwietnia dowodzacy przednią strażą austriacka pułkownik Andreas hrabia Karaiczay de Wallje-Szaka ${ }^{19}$ odebrał wiadomość, że duża liczba kawalerii tureckiej bitym gościńcem daży do Bacău. Rozkazał więc swoim ludziom kantonujacym w Faraoani i okolicznych miejscowościach wystapić w pole i opatrzył ich armatami. Zaledwie Karaiczay wydał dyspozycje do potyczki, ukazało się 5000 spahisów. Turcy pokonali rów pełen wody i wpadli $z$ impetem na huzarów. Ponieważ jazda turecka liczebnie przeważała nad Austriakami, pułkownik Karaiczay nakazał swym kawalerzystom cofnać się nieco pod armaty, z których raz za razem strzelano do nieprzyjaciela. Turcy poprzestali przeto na pierwszym ataku przeciwko centrum austriackiemu i zwrócili całą swoja potęgę na lewe skrzydło przeciwnika. Jednak kule armatnie i kartacze, jak również dzielny opór huzarów zmusiły ich do odwrotu. Spahisi zebrali się ponownie i natarli na środek oraz prawe skrzydło korpusu cesarskiego $z$ taką natarczywością, że dostali się do infanterii i armat. Lecz i tu ogień artyleryjski nie pozwolił im długo zabawić. Ostatecznie Austriacy odparli atak nieprzyjaciela. Turcy stracili w tej potyczce ok. 200 ludzi i 100 koni. Po stronie zwycięzców padło 14 ludzi i 13 koni, ciężko rannych zostało 32 ludzi i 50 koni. „Tu się znowu pokazało - konkludował Świtkowski - co może na wojnie taktyka i karność wielka. Turków było 5000 kawalerii, co do męża i konia najwyborniejszej. Cesarskich zaś było tylko ok. 1100 konnych i 800 kilkadziesiąt ludzi infanterii. Lecz przeciw infanterii w kwadrat uszykowanej i kawalerii zawsze ścieśnionemi szeregami potykającej

17 Ibidem, s. 506-509.

18 Por. C. von Wurzbach, op. cit., T. II, Wien 1857, s. 395-398.

19 Por. J. Hirtenfeld, op. cit., s. 293-295. 
się i od doświadczonego wodza naprowadzanej, nic nie może ślepa rozwiązła i do jednego celu zmierzająca zapalczywość"20. Austriacy odnieśli także zwycięstwo nad Tatarami, którzy w liczbie 8000 żołnierzy chcieli niezauważalnie przedrzeć się z Multan do Bukowiny, lecz zostali odkryci i zmuszeni do odwrotu. Na innych obszarach Osmanie mieli nieco więcej szczęścia. W Chorwacji puścili $z$ dymem wieś Glina i wyrżnęli w pień jej mieszkańców. Spalili też kilka wiosek w Transylwanii i wyparli Austriaków z Gura Lotra ${ }^{21}$.

W dalszej części artykułu redaktor „Pamiętnika” informował, że wojska rosyjskie, „zawsze prawie później od innych narodów kampanie rozpoczynajacce", otwarły ja tego roku bardzo wcześnie. W armii imperatorowej zaszły odmiany. Feldmarszałek Piotr Rumiancew Zadunajski został odwołany do Petersburga, a na jego miejsce przysłano księcia Nikołaja Repnina. Obie armie, Jekatierynowska i Ukraińska, oddano pod komendę księcia Potiomkina, który w nagrodę za zajęcie Oczakowa został ogłoszony feldmarszałkiem. Naczelny wódz do maja pozostawał w Petersburgu, nie spiesząc się zanadto $z$ wyruszeniem $\mathrm{w}$ pole. Turcy uznali, że zmiany w wojsku Katarzyny II moga działać na ich korzyść, dlatego też w znacznej liczbie poczęli zbierać się w Multanach i maszerować ku Jassom. Zamysłem ich było uderzyć na nieprzyjaciół, jak tylko ci wyrusza $z$ obozu pod Jassami, gdzie spędzili cała zimę. Uprzedzajacc te działania, generał lejtnant Otto Wilhelm Derfelden (Dorfelden) na czele kilkutysięcznego korpusu zaatakował Turków pod Măximeni i rozproszył ich na wszystkie strony (16 kwietnia). Do niewoli rosyjskiej dostało się dwóch baszów i kilkaset żołnierzy. Rosjanie, korzystajacc $z$ klęski nieprzyjaciela, zapuścili się pod Gałacz i mimo mężnej obrony garnizonu tureckiego miasto to szturmem zdobyli. Otwierając nowa kampanię zatem, wojska sojusznicze dotarły aż po Dunaj, opanowały Multany (Muntenia) i część Wołoszczyzny. Świtkowski stwierdził, że tylko walna bitwa wydana przez wielkiego wezyra, obozującego po drugiej stronie Dunaju, mogła przeszkodzić $\mathrm{w}$ zajęciu reszty tego terytorium. $Z$ kolei utrata Wołoszczyzny niechybnie pociagnęłaby za soba upadek Bendery i stratę całej Besarabii. Jednak w tym samym czasie w Konstantynopolu wydarzyło się coś, co związało ręce wielkiemu wezyrowi. Dnia 7 kwietnia 1789 r. zmarł niespodziewanie - w wieku 64 lat - cesarz turecki Abdulhamid I. Władze po nim obją jego syn, 28-letni Selim III, zdecydowany

20 PHPE, maj 1789, s. 512-513.

${ }^{21}$ Ibidem, s. 509-514. 
przywrócić dawny blask i potęgę Imperium Osmańskiemu. Wielki wezyr musiał czekać na rozkazy nowego sułtana i patrzeć spokojnie na postępy wojsk austriacko-rosyjskich po drugiej stronie Dunaju ${ }^{22}$.

Otwierając czerwcowe doniesienia $z$ wojny wschodniej, redaktor „Pamiętnika” pisał: „Tak szczęśliwe powodzenie przedniej straży wojsk rosyjskich w Mołdawii i tak rychłe, a natarczywe napadanie wojsk tureckich na różne poczty cesarskie w Transylwanii i Kroacji, toż udanie się do Węgier i Kroacji feldmarszałków Hadyka i Laudona, które się trafiły miesiąca przeszłego, obiecywały w tym miesiącu przypadki wojenne bardzo wielkie i ważne. Jednak mniejsze one były nad spodziewane"23. Generał Derfelden, mający pod rozkazami nie więcej jak kilka tysięcy żołnierzy, widząc, że główne wojsko rosyjskie leniwie za nim podąża, a wielki wezyr nieliczne hufce zaczał przesyłać za Dunaj, wycofał się z Gałaczu. Wcześniej jednak wspomniane miasto ograbił i doszczętnie spalił. Turcy niezwłocznie wzięli w posiadanie to pogorzelisko. W Transylwanii i Banacie nic znacznego się nie wydarzyło, jednak na granicach chorwackich wojska osmańskie wykazały się większą aktywnością. Jeszcze 22 maja Osmanie w sile 16000 wpadli na forpoczty cesarskie rozłożone obozem pod Obergrahovo i po uporczywej obronie je rozbili. Pomknęli dalej do Tubar, gdzie oddziały cesarskie usiłowały ich zatrzymać, jednak bez powodzenia. Dopiero pod Dobrozello po trwajacej 10 godzin walce hufce chorwackie zatrzymały przeciwnika i zmusiły go do odwrotu. Turcy swoim zwyczajem spalili kilka wsi, wzięli w jasyr kilkaset kobiet i mężczyzn, resztę zaś wycięli w pień.

W dalszej części artykułu Świtkowski informował, że feldmarszałek Laudon na początku czerwca 1789 r. zebrał 19 batalionów piechoty, 10 szwadronów kawalerii i udał się $z$ nimi na granicę turecka. Tłumaczył dalej, że przyczyna bezczynności austriackiego dowódcy były trudności aprowizacyjne. Kiedy na początku maja przybył on $z$ wojskiem na granicę, nie znalazł przygotowanych magazynów i musiał dopiero je urządzać. Ten sam niedostatek żywności i amunicji wstrzymał na jakiś czas działania feldmarszałka Hadika, komenderującego stutysięczną armią w Syrmii i Banacie. Dopiero pod koniec czerwca stanał on obozem w Weiskirchen i rozpoczał oblężenie Semendrii. Ponieważ Turcy w większej liczbie pojawili się na Wołoszczyźnie i zachodziła obawa, że będa próbowali wedrzeć się

${ }^{22}$ Ibidem, s. 514-517, 548-549. Por. W. Kalinka, op. cit., s. 474.

${ }^{23}$ PHPE, czerwiec 1789, s. 628. 
do Transylwanii, Hadik posłał tam kilka regimentów jazdy i piechoty. W zakończeniu wydawca "Pamiętnika” pisał, że plany wielkiego wezyra nie sa na razie znane. Stoi on ze swym wojskiem nad Dunajem przy Sylistrii, zagrażając wojskom cesarskim w Banacie i Transylwanii, a rosyjskim w Mołdawii i Besarabii. Czeka na dyspozycje Selima III. Ten złożył z urzędu starego kapudana paszę i uczynił go seraskierem Izmaiłu. Oddał mu komendę nad 80000 ludzi i polecił odzyskać Oczaków. Sułtan chciał wysłać w pole pół miliona zbrojnych, lecz niedostatek żywności utrudniał zwerbowanie takiej ich liczby ${ }^{24}$.

W numerze lipcowym Świtkowski donosił o dalszych postępach armii cesarskiej. Feldmarszałek Laudon zaniechał plan zdobycia zamku Czetyn i zwrócił się ku Sklawonii z zamiarem opanowania tureckiej Gradiški (Berbiru). Dnia 20 czerwca wojsko i artyleria przeznaczone do oblężenia stanęły pod Starą Gradišką (austriacką). Generał artylerii Johann Theodor baron von Rouvroy ${ }^{25}$ niezwłocznie przygotował działa do przeprawy przez Sawę. Austriacy dostrzegli, że po drugiej stronnie rzeki Bośniacy zbierają się i mogą rozłożyć obóz w pobliżu Gradiški, utrudniając przeprawę wojskom. Uprzedzając ich działania, Laudon nakazał pospiesznie zbudować most na rzece i w nocy 23 czerwca przeprawił przez niego swoich żołnierzy. Rozstawił obóz tak, że jedno skrzydło znajdowało się nad Sawa, drugie nad rzeką Verbaska, pozostała część oddziału opasała zaś twierdzę. W nocy Austriacy rozstawili baterie, a nad ranem wzięli się do usypywania pierwszych szańców. Każdego dnia wystawiano baterie coraz bliżej nieprzyjaciela. Laudon starał się działać powoli i rozważnie. Miał bowiem do dyspozycji oddział liczacy 15000 żołnierzy, podczas gdy Bośniaków było dwa razy tyle i spodziewano się odsieczy. Kolejnym dowodem przezorności austriackiego dowódcy było to, że „fortecy nie obległ ściśle ze wszystkich stron, ale $z$ jednej, gdzie był niedaleko las wielki, zostawił przejście wolne, aby garnizon nie był przywiedziony do rozpaczy, która Turków tak strasznemi i prawie niezwyciężonemi czyni" ${ }^{26}$. Taktyka ta niebawem przyniosła owoce. Kiedy bowiem Rouvroy przez kilka dni bezustannie zasypywał fortecę kulami, rozpalonymi bombami i workami $z$ prochem, a spodziewana odsiecz nie nadchodziła, 8 lipca Turcy opuścili Gradiškę i uszli do lasu. Nazajutrz Austriacy wkroczyli do

\footnotetext{
${ }^{24}$ PHPE, czerwiec 1789, s. 628-632, 646.

${ }^{25}$ Por. C. von Wurzbach, op. cit., T. XXVII, Wien 1874, s. 175-177.

${ }^{26}$ PHPE, lipiec 1789, s. 713-714.
} 
opuszczonej twierdzy. W magazynach znaleziono 35 armat metalowych, cztery żelazne oraz spora ilość amunicji. Wieść o zajęciu Berbiru niezmiernie uradowała Józefa II, a jeszcze bardziej to, że sukces ten okupiony został niewielkimi stratami. Przez całe oblężenie nie zginęło bowiem więcej niż 38 żołnierzy i trzech robotników, ranne były 133 osoby $^{27}$.

Tymczasem główna armia cesarska w dalszym ciąu pozostawała w bezczynności. Feldmarszałek Hadik wkrótce po przyjeździe do Banatu zapadł na febrę. Komendę nad wojskiem objął czasowo generał François Sébastien de Croix hrabia de Clerfayt ${ }^{28}$. Ale i po stronie tureckiej nie podejmowano większych działań. Powodem tego było złożenie $z$ urzędu wielkiego wezyra. Na jego miejsce został wybrany seraskier Widynia Kugian Hasan Pasza. Wojska lądowe i morskie zatem otrzymały nowych wodzów naczelnych. Świtkowski przypuszczał, że kapudan pasza i wielki wezyr zostali odwołani do Konstantynopola, gdyż byli zwolennikami prowadzenia wojny. Tymczasem Selim III, który zasiadł na tronie $z$ mocnym postanowieniem kontynuowania wojny aż do ostatecznego jej rozstrzygnięcia, poczał skłaniać się ku pokojowi. W całej Azji panowała bowiem wielka drożyzna, a w samej stolicy, Bułgarii i Rumelii brakowało żywności. Oprócz tego na skutek działalności korsarzy rosyjskich wystapiły trudności z zaopatrzeniem armii nad Dunajem. Przywrócenie żeglugi tureckiej na Morzu Czarnym wymagało wysłania tam floty. Sułtan wzbraniał sie jednak przed takim rozwiązaniem, obawiając się, by nie została ona pobita jak w roku poprzednim. Wtedy los Konstantynopola byłby przesadzony ${ }^{29}$.

Dlaczego jednak wojska austriackie i rosyjskie nie korzystały $z$ bezczynności Porty i nie wkraczały w głąb Wołoszczyzny? Powodem tego był głód i braki aprowizacyjne. Dowożenie żywności o 40-50 mil było niezmiernie trudne i wielce kosztowne, Turcy zaś stosowali taktykę spalonej ziemi na terenach, które musieli oddać nieprzyjacielowi. „W całej Mołdawii nie masz chleba, zboża, ani słomy, ani siana. Wszystkie pola sa spustoszone albo opuszczone, większa część rolników rozeszła się w różne strony za chlebem"

${ }^{27}$ Ibidem, s. 711-714, 744-745. Więcej na ten temat por. F. Tau b man n, Vita e fatti eroici Barone Gedeone di Laudon, tradotta la prima volta dal tedesco, parte 1, Firenze 1790, s. 18-36; G.B. Malle s o n, Loudon: A Sketch Of The Military Life Of Gideon Ernest, Freiherr Von Loudon, Sometimes Generalissimo Of The Austrian Forces, London 1884, s. 223-226.

${ }^{28}$ Por. J. Hirtenfeld, op. cit., s. 284-287.

${ }^{29}$ PHPE, lipiec 1789, s. 716-718. 
- donosił Świtkowski ${ }^{30}$. Co do wojsk rosyjskich, Potiomkin na czele 70000 żołnierzy miał strzec Oczakowa, podczas gdy książę Repnin $z$ resztą wojska szykował się do ataku na Bendery ${ }^{31}$.

W sierpniu 1789 r. na łamach „Pamiętnika” ukazał się obszerny artykuł omawiajacy działania wojenne na Wschodzie. Donoszono, że główna armia cesarska w tym miesiącu nie ruszyła się jeszcze $z$ obozu. Sędziwy feldmarszałek Hadik, widząc, że jego zdrowie się pogarsza, złożył najwyższą komendę w ręce cesarza, a ten oddał ja Laudonowi. W obozie zapanowało poruszenie. „Ciężkiej artylerii jeszcze więcej $z$ Peterwaradynu i Wiednia Dunajem pod Zemlin [Semlin - przyp. M.K.] spuszczono, drabin do szturmu kilka tysięcy sprowadzono, bomb, kul wielkich straszne mnóstwo na wozy wpakowano i flotyllę ciężka artylerią opatrzona pod Zemlin spławiono" - pisano na łamach „Pamiętnika”32. Wkrótce potem wśród żołnierzy rozeszła się wieść, że $z$ przybyciem Laudona wojsko zostanie przeprawione za Dunaj i rozpocznie się oblężenie Belgradu.

Tymczasem Turcy, korzystając $z$ bezczynności armii austriackiej w Banacie i Syrmii, skierowali swoje kroki do Transylwanii i Mołdawii. Wielki wezyr wyprawił za Dunaj 40000 żołnierzy, którzy połączyli się z wojskiem hospodara wołoskiego Mikołaja Mavrogheniego. Armia ta podzieliła się na dwie części, z których jedna miała wkroczyć do Transylwanii, a druga podążyć przeciwko Coburgowi i wojskom rosyjskim w Mołdawii. Dnia 15 lipca 8500 Turków ruszyło $z$ Milui ku szlakowi Tömes w Transylwanii i wpadli $z$ impetem na szaniec Prödialski, obsadzony trzema kompaniami piechoty pod dowództwem majora Layriza i trzema armatami. Po trwajacej kilka godzin walce ze znacznymi stratami zostali jednak odparci i zmuszeni do cofnięcia się. Dnia 4 sierpnia inny oddział turecki, w sile 14000 ludzi, usiłował wedrzeć się do Banatu przez szlak Bozawski. Turcy uderzyli na Austriaków obozujących pod Mehadia, lecz zostali pobici ${ }^{33}$.

Te małe straty były zaledwie zwiastunami większych nieszczęść, jakie przydarzyły się Osmanom tego miesiąca w Multanach. Książę Coburg odebrawszy wiadomość, że Mavrogheni ciagnie $z$ wojskiem ku granicom multańskim i że pod Fokszanami (Focșani) znajduje się już 20000 Turków, zaproponował operującemu w pobliżu

\footnotetext{
30 Ibidem, s. 719.

${ }^{31}$ Ibidem, s. 718-721.

32 PHPE, sierpień 1789, s. 829.

${ }^{33}$ Ibidem, s. 828-833.
} 
generałowi Aleksandrowi Suworowowi, by połączonymi siłami uderzyli na nieprzyjaciela, uprzedzając jego działania. Odpowiadając na to wezwanie, dywizja Suworowa (6000 żołnierzy) podjęła gwałtowny marsz i w ciagu 24 godzin pokonała aż 10 mil drogi z Bârladu do Adjud, gdzie obozowali Austriacy. Dnia 28 lipca o godzinie $11 \mathrm{w}$ nocy Rosjanie połączyli się z korpusem Coburga (15 000 żołnierzy). Przez cały następny dzień wojska odpoczywały. Tego dnia położono też trzy mosty na rzece Trotuş, $z$ których pierwszy miał zasłaniać pułkownik Karaiczay, dwa pozostałe zaś pułkownik Samuel von Kepiro ${ }^{34}$ $z$ dwiema dywizjami huzarów i jednym batalionem infanterii. Obaj wodzowie uzgodnili następujące rozłożenie wojsk do boju. Korpus cesarski stanał $z$ prawej strony $z$ pięcioma batalionami w pierwszej linii i czterema w drugiej. Każdy batalion był uszykowany w czworobok i miał po pięć armat. Artyleria należąca do rezerwy została rozstawiona między batalionami, jazda uszykowana w trzeciej linii za piechota. Infanteria rosyjska, uszykowana w trzy czworoboki w pierwszej linii i w dwa czworoboki w drugiej linii, stanęła $z$ lewej strony. Kawaleria ustawiła się tak samo jak cesarska, w trzeciej linii za infanterią. Niewielki oddział pułkownika Karaiczaya zajął pozycję między Rosjanami i Austriakami, Arnautom (Albańczykom) natomiast wyznaczono miejsce za konnica ${ }^{35}$.

Dnia 30 lipca o godzinie 3 nad ranem wojska sojusznicze ruszyły trzema kolumnami, przebyły rzekę Trotuş i dotarły aż do Călimănești. Podczas marszu pułkownik Karaiczay prowadził awangardę przed Rosjanami, a pułkownik Kepiro zasłaniał swoja jazda dwie pozostałe kolumny. Pod Călimănești wojsko stanęło w szyku, ale jak tylko popasły się konie i ludzie odpoczęli, podjęło marsz ku Mărăşeşti. Stąd 30 lipca wieczorem armia austriacko-rosyjska ruszyła w dalszą drogę, lecz już tylko dwiema kolumnami, z których jedna zasłaniał jazda pułkownik Karaiczay, a druga Kepiro. Krótko przed rozpoczęciem marszu Kozacy rosyjscy dali znać o zbliżającym się patrolu tureckim (3000 żołnierzy), za którym podążał Osman Pasza z oddziałem liczącym 7000 ludzi. Suworow wysłał przeciw niemu 1500 Kozaków i Arnautów, jak równiej dywizję Karaiczaya. Turcy, gdy tylko postrzegli Kozaków, zaatakowali ich i ich

${ }^{34}$ C. von Wurzbach, op. cit., T. XI, Wien 1864, s. 169.

35 PHPE, sierpień 1789 , s. 833-836. Walerian Kalinka (op. cit., s. 475) podaje, że korpus Coburga liczył 18000 żołnierzy. Według Andrzeja Andrusiewicza austriacki dowódca miał pod rozkazami 12000 żołnierzy, a Suworow 6000. Por. i d e m, Katarzyna Wielka. Prawda i mit, Warszawa 2012, s. 495. 
rozproszyli. Lecz major Michael Kienmayer ${ }^{36}$, dowódca austriackiego pułku, nie zważając na przewage liczebna przeciwnika, uderzył na Turków i zmusił ich do ucieczki. Zapędził się potem nad rzekę Putna, wyparł Osmana Paszę z obozu, a sam obóz puścił z dymem.

Tymczasem połaczone wojska austriacko-rosyjskie kontynuowały marsz. Dotarły nad rzekę Putna i położyły na niej most, który pułkownik Karaiczay zasłonił jazda. Gdy tylko spuszczono na wodę trzy pierwsze pontony, po drugiej stronie rzeki ukazali się Turcy, którzy próbowali udaremnić przeprawę. Jednak rozłożone w dwóch miejscach armaty odegnały przeciwnika, tak że most bez przeszkód dokończono. Nagłe wezbranie rzeki uniemożliwiło położenie drugiego mostu, toteż całe wojsko dnia 31 lipca rano zmuszone było jedną kolumna przeprawić się na druga stronę. Osmanie ponownie pojawili się nad rzeką. Uderzyli na awangardę Kozaków i Arnautów i ją rozproszyli. Natarli potem na Suworowa, lecz doznali porażki. Połaczone wojska, mimo że już od 18 godzin znajdowały się w marszu, przemierzyły kolejna milę przez teren krzewami i cierniami zarosły, „kiedy w gęstwienie konie nie mogły harmat ciągnąć, ludzie sami zastępowali je [..."37. Dotarłszy pod Fokszany, gdzie stał obozem Gazi Hasan Pasza, uderzyli na przeciwnika. Atak rozpoczęły wojska cesarskie zgrupowane na prawym skrzydle. Batalion Karl Schröder pod komenda pułkownika Karla Auersperga ${ }^{38}$ parł do przodu, rażąc nieustannie Turków $z$ armat. Kawaleria austriacka zbliżyła się do lewej flanki nieprzyjaciela i uderzyła na jazdę $z$ takim impetem, że ta od razu uciekła i umknęła za Fokszany. Inne trzy dywizje huzarów cesarza $z$ gołymi pałaszami wpadły na janczarów znajdujących się w tym samym skrzydle, którzy podobnie jak spahisi uciekli i schronili się w pobliskim klasztorze św. Samuela. W tym samym czasie Rosjanie i oddział Karaiczaya natarli na oszańcowane prawe skrzydło tureckie, zmuszając nieprzyjaciela do odwrotu. Dowódca batalionu Karl Schröder usiłował zająć klasztor, do którego zbiegli janczarzy, lecz padł trupem podczas próby sforsowania bramy. Niebawem pod klasztor przybył książę Coburg na czele batalionu ochotników, prowadząc ze sobą działa. Austriacy sforsowali mury klasztoru i wdarli się do środka, kładąc trupem wszystkich Turków. Reszta wojska Gazi Hasana (ponad 30000 żołnierzy) poszła w rozsypkę, zostawiajac zwycięzcom cały obóz, artylerię i dobrze zaopa-

\footnotetext{
36 J. Hirtenfeld, op. cit., s. 268.

37 PHPE, sierpień 1789, s. 842.

38 Por. J. Hirtenfeld, op. cit., s. 282-283.
} 
trzone magazyny. Zginęło co najmniej 1000 żołnierzy tureckich, a 96 dostało się do niewoli. Zdobyto 16 choragwi i 10 armat. Tego samego dnia (1 sierpnia) Austriacy zajęli jeszcze 100 wozów, którymi $z$ Braiła wieziono prowiant i amunicję do obozu tureckiego. Po bitwie generał Suworow wrócił na swą dawna pozycję w Mołdawii, a Coburg wkroczył na teren Wołoszczyzny. Rozproszonych po walce Turków zebrał Mavrogheni i seraskier Derwisz Mehmed Pasza. Obaj wodzowie stanęli znowu w polu, 6 mil od Fokszan, jednak bez namiotów, wozów i magazynów ${ }^{39}$.

„Jeśli miesiąc poprzedni był dla Turków niepomyślny, ten był jeszcze gorszy" - pisał Świtkowski w numerze wrześniowym ${ }^{40}$, omawiając wypadki na wschodnim teatrze działań wojennych. Redaktor „Pamiętnika” donosił, że po klęsce pod Fokszanami i Czernekiem (4 sierpnia) Turcy postanowili spróbować szczęścia w Banacie. Wdarli się tam od strony Orszowy, w liczbie 6000 ludzi, i stanęli obozem pod Mehadią. Dowodzący wojskiem na tym odcinku generał Clerfayt pospieszył przeciwko Osmanom. Pobił ich i zapędził wysoko w góry (28 sierpnia). Tymczasem główna armia cesarska zbierała się pod Semlinem. Dnia 3 września przybył tam feldmarszałek Laudon, a nazajutrz arcyksiążę Franciszek. Planowano oblężenie Belgradu. Laudon miał do dyspozycji 50000 żołnierzy, 700 ciężkich dział, mnogość amunicji i bomb różnego kalibru, 140 moździerzy, 150 statków zbrojnych i 10000 robotników do kopania szańców. Kiedy już całe wojsko zgromadziło się w obozie, głównodowodzący powierzył nadzór nad szańcami, sypaniem baterii i ustawianiem na nich armat generałowi artylerii Karlowi Clemensowi hrabiemu Pellegrini ${ }^{41}$, a bombardowanie generałowi Johannowi Theodorowi

${ }^{39}$ PHPE, sierpień 1789 , s. 837-845. Por. F. Taubmann, op. cit., s. 47-50; A. Andrusiewicz, op. cit., s. 495; S.S. Mon te fior e, Potiomkin, książę ksiażąt, Warszawa 2000, s. 497; idem, Katarzyna Wielka i Potiomkin, Warszawa 2013, s. 525 (w obu swoich pracach Montefiore podaje, że w bitwie poległo ponad 1500 żołnierzy tureckich); I. de Madariaga, Russia in the Age of Catherine the Great, London 1981, s. 409 (tu informacja, że korpus księcia Coburga liczył 18000 żołnierzy, czyli o 3000 więcej, niż podała gazeta Świtkowskiego); oraz F. A n thing, History of the campaigns of Count Alexander Suworow Rymnikski, field-marshalgeneral in the service of His Imperial Majesty, the Emperor of all the Russias: with a preliminary sketch of his private life and character, vol. II, London 1799, s. [55-71] (tu również wzmianka o tym, że wojsko austriackie liczyło 18 000, a rosyjskie 7000 żołnierzy. Straty tureckie wynosiły 2000 zabitych i ok. 300 wziętych do niewoli).

${ }^{40}$ PHPE, wrzesień 1789, s. 944.

${ }^{41}$ Generał Karl Clemens hrabia Pellegrini zm. w Wiedniu 28 XI 1796 r. Por. C. von Wurzbach, op. cit., T. XXI, Wien 1870, s. 440-443. 
baronowi von Rouvroy. Dnia 12 września ukończono most na Sawie, po którym przeprawiło się wojsko liczące 40000 piechoty i 9000 jazdy. Nazajutrz Austriacy opasali twierdzę i zaczęli zakładać baterie, $z$ których najdalsze znajdowały się w odległości zaledwie 900 kroków od twierdzy. W obwodzie pozostawał korpus generała Clerfayta. Miał on odeprzeć atak dawnego komendanta Belgradu Abdy Paszy, idącego na odsiecz obleganemu miastu z 40000 żołnierzy. Laudon był niestrudzony. Przez dwa dni prawie nie zsiadał $z$ konia, doglądając wszystkiego. „Turcy zaś, choć im ma być do obrony 15000 w Belgradzie - donosił Świtkowski - zamiast bronienia przeprawy i robienia mostów, zamiast przeszkadzania w nocy do sypania baterii, modla się w meczetach i prorokowi fortecę poruczają. Dopiero dnia 14 ich harmaty i czajki chciały przeszkadzać do sypania baterii przy ujściu Sawy, kiedy ta już była gotowa i przedmieście ich paliła"42. Turcy pozostawali w bezczynności także na innych terenach. Ich flota stała spokojnie pod Oczakowem, seraskier pod Izmaiłem, wielki wezyr zaś na Wołoszczyźnie, chcąc przeszkodzić w dalszym marszu wojskom Repnina, Suworowa i Coburga ${ }^{43}$.

Kolejny artykuł na temat wojny wschodniej ukazał się w październiku 1789 r. Ksiądz redaktor powrócił w nim do wątku oblężenia i zajęcia Belgradu, jak również omówił wypadki rozgrywające się na Wołoszczyźnie. Szturm Belgradu rozpoczął się 30 września o godzinie 10 rano. Wojska biorace udział w ataku podzielone były na cztery kolumny. Austriakom udało się zająć przedmieścia i wyprzeć stąd Turków, którzy schronili się w zamku. Laudon zażądał poddania fortecy. Dowódca garnizonu tureckiego Osman Pasza odpowiedział kanonada ze wszystkich dział. W nocy 5 października głównodowodzący armii cesarskiej nakazał usypanie nowych baterii. Nazajutrz otwarto $z$ nich ogień, który wywołał kilka pożarów w mieście. Około południa pasza turecki przysłał list z prośbą o zawieszenie działań wojennych na 15 dni. Laudon rozkazał ponownie ostrzelać fortecę bombami i rozpalonymi kulami. Ostrzał trwał przez cała noc, przynoszac obrońcom znaczne straty (1200 zabitych). Dnia 8 października Osman Pasza podpisał warunki kapitulacji. Garnizon miał wyjść $z$ Belgradu $z$ całym majątkiem, pozostawiwszy w środku armaty, amunicję, furaże i czajki. Żołnierze tureccy mieli być odesłani do Orszowy pod eskortą Austriaków.

42 PHPE, wrzesień 1789, s. 949-950.

43 Ibidem, s. 944-950. Por. F. Taubmann, op. cit., s. 65-72; G.B. Malle s on, op. cit., s. 227-229. 
Sprzęt i żywność osób prywatnych mogła być sprzedana. Wraz z Turkami twierdzę mogli opuścić Żydzi, chrześcijanie i renegaci. Dezerterzy i więźniowie austriaccy mieli być wydani zwycięzcom. Żołnierze otrzymali zakaz zbliżania się do kobiet tureckich i obcowania $z$ nimi. W trakcie poddania twierdzy garnizon obrońców liczył 7000 ludzi, między którymi było 1000 rannych. W ręce zwycięzców wpadły potężne łupy wojenne: 400 armat różnego kalibru, 6000 cetnarów prochu strzelniczego, wielka liczba kul i różnej amunicji. Była to pierwsza ważna zdobycz armii cesarskiej w tej wojnie. Kosztowała Austriaków jedynie ok. 500 zabitych i ponad 700 rannych. „Jak ta zdobycz ucieszyła cesarza - pisał Świtkowski - trudno wymówić, $z$ Belgradem ujrzał on się być znowu panem całej Serwii [Serbii - przyp. M.K.], która roku 1739 odpadła była od Domu Austriackiego"44.

W dalszej części artykułu zamieszczono szczegółową relację z bitwy nad Rymnikiem, zwana także bitwą pod Martineszti (Mărtinești). Po klęsce Turków pod Fokszanami wielki wezyr Rudschuk Hassan, następca Jusufa Paszy, przeprawił się przez Dunaj na czele armii liczącej 100000 żołnierzy (w większości kawalerii) i stanał obozem pod Gałaczem. Zamierzał połaczyć siły z Mavroghenim, by pobić ostatecznie korpus Coburga. O planach tych austriacki dowódca dowiedział się $z$ listu wielkiego wezyra, przechwyconego przez huzarów cesarskich. Wezwał Suworowa na pomoc. Ten niezwłocznie zebrał swoją dywizję rozłożoną między Prutem a Seretem i wydał rozkaz do marszu. Dnia 21 września Rosjanie połączyli się z Austriakami operujacymi w rejonie Fokszan, a nazajutrz sprzymierzone wojska przeprawiły się przez rzekę Rymnę. Korpus rosyjski, wzmocniony dwiema dywizjami huzarów cesarskich, skierował się przeciwko obozowi Mavrogheniego pod Tyrgukukuli (Tyrgu-Kukuli), Austriacy zaś zwrócili się w kierunku rzeki Rymnik i stanęli w równej linii $z$ obozem wielkiego wezyra. Takie rozłożenie wojsk Coburga zapewniało im łączność $z$ oddziałem Suworowa. Nad ranem Turcy postrzegli wojska rosyjskie i $z$ impetem na nie uderzyli. Rosjanie wytrzymali gwałtowny atak przeciwnika i zmusili go do odwrotu. Wielki wezyr posłał Mavrogheniemu na pomoc 18000 kawalerii, która natarła na lewe skrzydło rosyjskie. Coburg wsparł Suworowa $z$ prawej strony. Turcy zostali odparci i zmuszeni do ucieczki.

${ }^{44}$ PHPE, październik 1789, s. 1037-1043 (cyt. na s. 1042-1043). Więcej na temat oblężenia i zajęcia Belgradu por. F. Tau b man n, op. cit., s. 73-79, 109-122; G.B. Malles on, op. cit., s. 230-232. Por. też W. Kalinka, op. cit., s. 476. 
Tymczasem reszta korpusu cesarskiego przedarła się przez krzaki i stanęła naprzeciw armii wielkiego wezyra ${ }^{45}$.

Cała infanteria turecka, składająca się z 40000 janczarów, rozstawiona była przed lasem, który dzielił oba obozy. Z przodu usypane były okopy, a $z$ prawej i lewej strony lasu znajdowała się kawaleria. Turcy ostrzelali nieprzyjaciela $z$ armat i natarli na cały front wojsk zjednoczonych. Próbowali także okrążyć Rosjan zgrupowanych na lewym skrzydle, lecz bezskutecznie. Wielki wezyr pchną kilka tysięcy konnych wraz $z$ sześcioma armatami przeciwko prawemu skrzydłu armii sprzymierzonych, gdzie stała brygada generała Karaiczaya. Turcy siedem razy ponawiali atak, zostali jednak odparci przez Karaiczaya z pomoca Suworowa. Zbici spahisi cofnęli się do okopów. Wojska austriacko-rosyjskie odebrały rozkaz uszykowania się w półcyrkuł i ruszenia na nieprzyjaciela, co przywitano gromkim okrzykiem. Obaj głównodowodzący $z$ innymi generałami w czasie tego ataku, a także podczas całej bitwy znajdowali się na czele armii. Turcy ostrzelali przeciwnika $z$ armat i ręcznej strzelby. Wodzowie zjednoczonych wojsk, chcąc zmniejszyć straty w szeregach, rzucili kawalerię przeciwko tureckiej piechocie, która poszła w rozsypkę. Za kawalerią nadciagnęła infanteria. Wdarła się na okopy, opanowała armaty i zmusiła Osmanów do ucieczki w las. Zwycięstwo przechyliło się na stronę wojsk zjednoczonych, jednak zbitego i rozproszonego przeciwnika trzeba było jeszcze gonić, żeby się nie zebrał i w oszańcowanym obozie nad Rymnikiem nie chciał bronić. Lecz żołnierze tureccy, widząc, że nieprzyjaciel puścił się za nimi pędem, porzucili i ten obóz, pozostawiając całą artylerię, amunicję, namioty i bagaże. W wodach Rymniku Austriacy znaleźli nadto 4000 fur ładownych, wiele armat i moździerzy, wozy $z$ amunicją, beczki $z$ prochem, ryżem, konie, wielbłądy, bawoły i owce „tak w kupe pomieszane, iż rzeka niejako została zatamowana”. Według relacji wziętych do niewoli Turków armia wielkiego wezyra liczyła przed bitwą 100000 żołnierzy, a zatem pięciokrotnie przewyższała liczebnością wojska austriacko-rosyjskie. Bitwa rozpoczęła się o wschodzie słońca i trwała niemal do zachodu, 11 godzin, przy nieustannym strzelaniu $z$ dział. Na placu legło ok. 4000 Turków, ale w niewolę dostało się jedynie 39, gdyż żołnierze osmańscy woleli ginąć niż prosić o pardon ${ }^{46}$.

45 PHPE, październik 1789, s. 1043-1048.

46 Ibidem, s. 1049-1054. Więcej na ten temat por. F. Taubmann, op. cit., s. 50-59; F. Anthing, op. cit., s. [79-107]. W tej ostatniej pracy czytamy, że straty 
$\mathrm{Na}$ innym odcinku frontu (Wołoszczyzna) książę Friedrich Wilhelm von Hohenlohe-Kirchberg ${ }^{47}$ na czele 6000 żołnierzy uderzył na obóz paszy tureckiego Kara Mustafy. Jak donosił Świtkowski: „Turcy potykali się mężnie i po dwakroć bitwę stoczyli, ale jednak byli zbici i rozproszeni, zostawiwszy na placu 1200 ludzi i 6 harmat"48. Straty Austriaków w obu tych bitwach wynosiły 600 żołnierzy. Również Rosjanie mieli się czym poszczycić. Suworow pobił korpus turecki pod dowództwem Gazi Hasana, dawnego kapudana baszy. Obległ ponadto twierdzę Izmaił w północnej części delty Dunaju i wzią ją szturmem ${ }^{49}$.

W listopadowym numerze redaktor „Pamiętnika” donosił o większej aktywności Rosjan na froncie południowym. Do końca sierpnia

tureckie wynosiły ogółem 10000 żołnierzy, w tym 5000 poległych w bitwie, 2000 zabitych w lesie lub zmarłych od ran, a 3000 utonęło w wodach Rymniku. Wielki wezyr w raporcie wysłanym do sułtana szacował swoje straty na 20000 ludzi, wliczając w to dezerterów. Straty zjednoczonych wojsk były niewielkie. Austriacy mieli 115 poległych w boju i 300 rannych, Rosjanie jedynie 57 zabitych i 110 rannych. Por. też S.S. Montefiore, Potiomkin..., s. 499; ide m, Katarzyna Wielka i Potiomkin..., s. 526-527 (autor ten podaje, że Turcy stracili w walce 15000 żołnierzy); I. de Madariaga, op. cit., s. 409; oraz Erläuterter Plan von der berühmten Schlacht bei Martinjestie in der Wallachey: in welcher unter den Befehlen sr. Durchlaucht des Herzogs Friedrich Josias von Sachsenkoburg, k. k. Generals der Kavallerie (nunmehrigen Feldmarschalls,) und des militärischen Theresienordens Großkreuz, der Großvezier mit 100000 seiner besten Truppen am 22. Sept. 1789 entscheidend geschlagen wurde, Prag 1789, s. 5-24. Dodajmy w tym miejscu, że w uznaniu zasług w tej bitwie cesarzowa nadała Suworowowi przydomek Rymnickiego. Odznaczyła go Orderem Świętego Jerzego pierwszej klasy, dekorowanym brylantami, podarowała szpadę z napisem: „Pogromcy wielkiego wezyra”, także wysadzana brylantami (wartość obu prezentów wynosiła bagatela 60000 rubli) i awansowała na podpułkownika pułku Prieobrażenskiego, a cesarz Józef II uczynił go hrabią. Również oficerowie i żołnierze obu korpusów zostali odpowiednio wynagrodzeni. Pierwsi otrzymali awans i odznaczenie, drudzy gratyfikację pieniężną. Tym, którzy w bitwie wyróżnili się w sposób szczególny, przyznano medal z inskrypcją „Rymnik”. Por. F. Anthing, op. cit., s. [110-111]; A. Andrusiewicz, op. cit., s. 497; S.S. Montefiore, Potiomkin..., s. 501; idem, Katarzyna Wielka i Potiomkin..., s. 529.

47 Por. Oesterreichisches Militär-Konversations-Lexikon. Unter Mitwirkung mehrerer Offiziere der k. $k$. Armee, redigirt und hrsg. von J. Hirtenfeld, Bd. III (H-Kulm), Wien 1852, s. 248-249.

48 PHPE, październik 1789, s. 1054. Por. W. Kalinka, op. cit., s. 475; F. Ta u bmann, op. cit., s. 46-47.

49 PHPE, październik 1789, s. 1054. Wieści o zajęciu fortecy Izmaił były przedwczesne. Rosjanie wzięli ją szturmem po wielomiesięcznym oblężeniu dopiero 11 (22) XII 1790 r. Por. A. Andrusiewicz, op. cit., s. 496-497; W. Serczyk, Katarzyna II carowa Rosji, Wrocław 1989, s. 265; Z. Ry niew icz, Leksykon bitew świata, Warszawa 2008, s. 228. 
1789 r. książę Potiomkin z głównymi siłami stał pod Oczakowem, gotowy bronić zdobytej $z$ tak wielkim trudem twierdzy. Widząc jednak, że flota turecka niewiele zdziałała w tych stronach i zawróciła pod Warnę, podzielił swoje wojska na dwie części. $Z$ jedna pomaszerował w kierunku Bender $\mathrm{z}$ zamiarem zajęcia tej fortecy, druga pod dowództwem księcia Repnina posłał przeciwko nadciagającemu seraskierowi. $Z$ tym ostatnim doszło do walki 20 września. Wojsko tureckie, „mało uszkodzone, ale dużo przestraszone”, uciekło za Dunaj, pozostawiając całą Besarabię na pastwę przeciwnika. Rosjanie mając wolna ręke, przystapili do oblegania twierdz naddunajskich. Opasali ściślej Bendery, gdzie generalissimus pozostawił część żołnierzy, a z reszta armii skierował się ku Akermanowi. Była to dobrze ufortyfikowana i zaopatrzona w różnego rodzaju amunicję forteca, ważna $z$ uwagi na strategiczne położenie (nad morzem i u ujścia Dniestru). Rosjanie zajęli ja bez strat i niemal bez walki w dniu 11 października. W ręce zdobywców dostało się 51 armat ustawionych na wałach i 37 na statkach wojennych. Krótko przedtem żołnierze rosyjscy wzięli szturmem zamek Chodszabo (Chodshabo ${ }^{50}$, a także zajęli Palankę w bliskości Akermanu ${ }^{51}$.

Oczyściwszy tereny nadmorskie $z$ nieprzyjaciół, Potiomkin ruszył na Bendery. „Garnizon liczny i potężne fortyfikacje - pisał ksiądz redaktor - w każdym innym czasie czyniłyby oblężenie i dobycie tej ważnej twierdzy bardzo trudnym i kosztowałoby wiele krwi ludzkiej. Lecz teraz, gdy wojska główne tureckie były zbite i rozproszone, a komendant widział, iż nie może się spodziewać odsieczy żadnej, i lud nie miał ochoty bronić się, uczynił co było najroztropniejszego, i poddał fortece 5 listopada, otrzymawszy pozwolenie, aby wolno z garnizonem do Kilia lub Sylistrii wyciagną"52. Rosjanie puścili wolno ośmiotysięczny garnizon i zajęli miasto liczące 30000 mieszkańców. Znaleźli w nim 360 armat spiżowych i 40 żelaznych, dużo amunicji i żywności. Zdobyto nadto 2000 koni kawaleryjskich. $Z$ tej strony Dunaju nie zostało Turkom nic oprócz Kilii ${ }^{53}$.

50 Nastapiło to 4 X 1789 r. Cf. Lettres à Monsieur le comte de B***, sur la révolution arrivée en 1789, sous le règne de Louis XVI, avec des Notes sur les Ministres et autres gens en place qui, depuis le regne de Louis $X V$, ont donné lieu à cette Révolution mémorable, par des déprédations ou des abus d'autorité, t. IV, Londres et Paris 1789, s. (284).

${ }^{51}$ PHPE, listopad 1789, s. 1116-1118.

52 Ibidem, s. 1118-1119.

53 Ibidem. Por. W. Kalinka, op. cit., s. 495; S.S. Montefiore, Potiomkin..., s. 499-500; idem, Katarzyna Wielka i Potiomkin..., s. 527; J.T. Alexander, 
Podczas gdy Rosjanie podbijali Besarabię i Budziak, wojska cesarskie zajęte były zdobywaniem Serbii i Wołoszczyzny. Po opanowaniu Belgradu feldmarszałek Laudon obrał za cel Orszowę (Orșova), położona na wyspie dunajowej niedaleko Mehadi, między Banatem, Serbią i Wołoszczyzna, która była niejako kluczem do tych trzech prowincji. Nakazał generałowi Ludwigowi Wilhelmowi hrabiemu Wartensleben ${ }^{54}$, komendantowi wojsk w Banacie, wziąć szturmem tę twierdzę. Po trudnym marszu w górzystym i błotnistym terenie 24 października korpus Wartenslebena stanał pod Orszową i niezwłocznie zajął przyległa górę Allion. Posłano do komendanta dwóch oficerów $z$ żądaniem poddania zamku. Basza turecki w ciagu 24 godzin odpowiedział na piśmie, że gotów jest bronić się do upadłego. Dnia 26 października Austriacy rozpoczęli oblężenie fortecy. Chcąc odciąć dowóz żywności z pobliskiej Kłodawy, generał Domenico Tomiotti de Fabris hrabia di Cassano ${ }^{55}$ przeprawił się przez Dunaj i zmusił tamtejszy garnizon (500 żołnierzy) do kapitulacji (6 listopada). Wraz z Kłodawą dostał się w ręce Austriaków „piękny i jeszcze podczas tej wojny nienaruszony" powiat Kraina, w którym znajdowało się ok. 150 miasteczek i wsi. Z kolei ksiażę F.W. von Hohenlohe-Kirchberg wkroczył do Wołoszczyzny i zają Krajowa. Zbliżająca się pora zimowa uniemożliwiła większe działania w Serbii, toteż wojsko cesarskie rozciagnęło tam kordon od Zvornika aż do Jagodiny nad rzeka Morawą. Coburg rozłożył swoich żołnierzy na kwaterach w Bukareszcie. Po stronie austriackiej na tym zakończyła się kampania 1789 r. Cesarz nie krył radości z odniesionych sukcesów. Wyniósł Coburga do godności feldmarszałka, przyznał mu krzyż wojenny i podarował pałac w Wiedniu. Z kolei Katarzyna II, która jeszcze po bitwie pod Fokszanami obdarowała generała kosztowna tabakierka, napisała do niego po zwycięstwie pod Rymnikiem, że „pierwszy raz dopiero jak jest imperatorowa znajduje się w niebezpieczeństwie nadgrodzenia tak wielkich zasług księcia, a dla tego oświadcza, że przynajmniej starać się będzie, żeby mu oświadczyć jak największą wdzięczność swoją"56.

Catherine the Great. Life and Legend, New York 1989, s. 279; I. de Madariaga, op. cit., s. 409 (tu podano, że garnizon turecki liczył 20000 żołnierzy).

${ }^{54}$ Por. J. Hirtenfeld, op. cit., s. 280-282.

55 Oesterreichisches Militär-Konversations-Lexikon..., Bd. II (D-G), Wien 1852, s. 268-269; J. Hirtenfeld, op. cit., s. 107-108.

56 PHPE, listopad 1789, s. 1120-1127 (cyt. na s. 1126). Por. F. Taubmann, op. cit., s. 118-132, 138-142. 
W grudniu 1789 r. Świtkowski donosił, że Austriakom nie udało się jeszcze wziąć szturmem Orszowy, której mury „podnoszą się prawie $z$ samej wody”, co czyni ją trudną do zdobycia. „Budynków w środku jest bardzo mało - czytamy w "Pamiętniku" - i te murowane, dlatego bomby nie mają tam co zapalić, a zaś kazamaty, w których się garnizon kryje, tak sa mocno sklepione, że ich stofuntowe bomby przebić nie moga" ${ }^{57}$. Biorac wszystko to pod uwage, Laudon zamienił oblężenie na blokadę, odesłał do Wiednia arcyksięcia Franciszka, a sam udał się do Bukaresztu, by wspólnie $z$ Coburgiem ułożyć dalsze plany wojenne. Józef II, naglony słabością zdrowia i rewolucja w Niderlandach, nakazał Peterowi Philippowi baronowi de Herbert-Rathkeal ${ }^{58}$ udać się do Bukaresztu i jak najprędzej uzgodnić pokój z wysłannikiem Porty. Tymczasem w Konstantynopolu Selim III odebrał od obu swoich wodzów listy z informacja, że wojska tureckie nie chcą dalej bić się z nieprzyjacielem. Zasmucony ta nowina, złożył $z$ urzędu wielkiego wezyra i ponownie powołał na to stanowisko byłego kapudana paszę Gazi Hasana, polecając mu zawrzeć pokój. Nowy wielki wezyr zaproponował armistycjum Potiomkinowi i Coburgowi, lecz ten pierwszy hardo oświadczył, że póty broni nie złoży, póki nie zostanie podpisany traktat. Zabiegający o pokój cesarz radził księciu Taurydy, aby nie stawiał Porcie zbyt twardych warunków. W końcowej części artykułu Świtkowski stwierdził, że dwór wiedeński obecnie nie tyle troszczy się o nowe nabytki terytorialne, co raczej o utrzymanie dotychczasowych ${ }^{59}$.

Do tematu mijającej kampanii Świtkowski powrócił jeszcze w numerze styczniowym redagowanego przez siebie czasopisma. Podjął w nim próbę bilansu zeszłorocznych działań wojennych, przybliżył negocjacje pokojowe między Porta i sprzymierzonymi dworami cesarskimi, jak również omówił przygotowania do nowej kampanii. W Konstantynopolu wieści o klęskach wojennych wywołały nie lada wrażenie. Dywan koniecznie chciał wiedzieć, jak to się stało, że pod Martineszti 18000 Austriaków i Rosjan pobiło stutysięczna armię wielkiego wezyra. Sułtan wysłał na miejsce bitwy zaufanych ludzi, by przedstawili mu cała okolice, stanowisko wodza naczelnego i rozłożenie wojsk sprzymierzonych. Osądzono później, że przyczyna doznanej porażki była w dużej mierze

57 PHPE, grudzień 1789, s. 1242.

58 C. von Wurzbach, op. cit., T. VIII, Wien 1862, s. 352-357.

59 PHPE, grudzień 1789, s. 1242-1245. Szczegółowo na temat oblężenia i blokady Orszowy por. F. Taubmann, op. cit., s. 132-137. 
nieudolność wielkiego wezyra. Złożono go więc $z$ urzędu i w celu uspokojenia pospólstwa nakazano aresztować i przyprowadzić do stolicy. Selim III, przerażony tak wielką stratą i hańbą, całą noc po odebraniu złej nowiny spędził na pisaniu hatti-szeryfu. Zarzucał w nim baszom „nikczemność w potykaniu się $z$ niewiernymi”, wystawiająca na niebezpieczeństwo cały naród i wiarę Mahometa. Zachęcał ich do mobilizacji sił i wzmożonych przygotowań wojennych $\mathrm{w}$ celu powetowania doznanych niepowodzeń. Zapowiedział także, że na wiosnę stanie na czele armii i albo dokona zemsty, albo $z$ innymi muzułmanami polegnie na placu boju. Ta rezolucja sułtana natchnęła odwaga Turków, lecz gdy nadeszły wieści o utracie Benderu, Akermanu, zwłaszcza zaś Belgradu, trwoga wzięła nad wszystkimi górę. Gabinet turecki podjął decyzję o zakończeniu wojny. Wkrótce po opanowaniu Bukaresztu, 8 grudnia hospodar wołoski Mavrogheni wysłał gońca do Potiomkina $z$ zapytaniem, gdzie i z kim Porta ma negocjować warunki pokoju. Serenissimus odpowiedział, że otrzymał od swojej monarchini stosowne pełnomocnictwo i wskazał Jassy na miejsce przyszłych rokowań. Wielki wezyr posłał tam niezwłocznie reis efendiego $z$ dużym orszakiem możnych tureckich. Na początku stycznia 1790 r. do stolicy Multan przybył ambasador rosyjski Jakub Bułhakow, uwolniony przez sułtana z Zamku (Twierdzy) Siedem Wież, a cesarz wysłał tam Franza Marię barona von Thugut ${ }^{60}$ i polecił Herbertowi przygotować się do wyjazdu. Dnia 13 stycznia Józef II odebrał wiadomość od Potiomkina, że reis efendi zabiega o sześciomiesięczne zawieszenie broni, nie zaś o pokój, i że Porta domaga się, aby zwrócono jej wszystkie utracone tereny. W tej sytuacji Herbert pozostał w Wiedniu, a za Thugutem pchnięto gońca $z$ rozkazem, by miast do Jassów udał się od Bukaresztu, gdzie miał rezydować jako gubernator prowincji wołoskiej. Sułtan turecki widzac, że bez większych ofiar i utraty zawojowanych krajów nie uzyska pokoju, zdecydował się kontynuować wojnę. Rozkazał, by na wiosnę baszowie zgromadzili się $z$ wojskami w Adrianopolu i zawezwał pod broń wszystkich wiernych w wieku od 18 do 60 lat. Aby napełnić pusty skarbiec, nakazał oddać do mennicy wszystkie srebra ${ }^{61}$.

${ }^{60}$ Więcej na jego temat por. C. von Wurzbach, op. cit., T. XLV, Wien 1882, s. 1-6; K.A. Roider, Baron Thugut and Austria's response to the French Revolution, Princeton 1987.

${ }^{61}$ PHPE, styczeń 1790, s. 90-93. O negocjacjach w Jassach por. S.S. M o n tefiore, Potiomkin..., s. 502, 511; idem, Katarzyna Wielka i Potiomkin..., s. 530, 539-540; I. de Madariaga, op. cit., s. 410. 
Dalej redaktor „Pamiętnika” informował, że w styczniu 1790 r. zelżały nieco wielkie mrozy. Turcy usiłowali wykorzystać poprawę pogody do wzmożonej aktywności na froncie. W Chorwacji dwukrotnie uderzyli na kordon cesarski w okolicy Czetyna, lecz nie mogli go sforsować. $Z$ kolei pasza Widynia pospieszył na odsiecz obleganej Orszowie. Osmanie w sile 5000 żołnierzy zaatakowali słabszy liczebnie oddział Austriaków, ubili $100 \mathrm{z}$ nich, a resztę zmusili do ucieczki. Niebawem Osmanie zjawili się pod Kłodawa, w murach której schronili się pobici żołnierze cesarscy, żądając poddania twierdzy. Jej komendant, pułkownik Anton von Liptay (Lipthay) ${ }^{62}$, wyszedł przeciw nim w pole $z$ czterema batalionami i 11 cugami huzarów. Turcy uderzyli na niego cztery razy, lecz zostali odparci i zmuszeni do odwrotu. Nieudana odsiecz paszy widyńskiego nie skłoniła jednak obrońców Orszowy do złożenia broni.

W zakończeniu Świtkowski pisał: „Zdaje się to rzeczą dziwną, że Turcy choć tak we wszystkich spotkaniach $z$ nieprzyjaciółmi swemi nieszczęśliwi, odważaja się jednak jeszcze na trzecia kampanią. Ale wiedzą oni, co się dzieje w Niderlandach. Nie tajny im alians bliski Prus z Polską. Podług wszelkiego pozoru kilkoletnie układy Anglii, Holandii i Prus już dojrzały i zabieraja się przeszkodzić, aby tak straszny i tak szczęśliwy alians cesarskich dworów nie stał się niebezpieczny dla niepodległości całej Europy"63. Stwierdził następnie, że sojusz Francji i Austrii na nic się teraz nie przyda Józefowi II. $\mathrm{Na}$ froncie północnym sytuacja rozwijała się pomyślnie dla Turcji. Gustaw III przygotowywał się do nowej kampanii, mobilizując wszystkie siły państwa. Chciał wystawić 70-tysięczną armię lądową i flotę galer dwukrotnie większą niż w roku minionym. Wątłe zdrowie cesarza musiało pociągać za soba niejaka opieszałość „w zamysłach i ich wykonaniu", a postrach Turków - Laudon wyjechał do Czech, gdzie miał objać komendę nad tamtejszym wojskiem. Nic więc dziwnego, że wobec tylu sprzyjających okoliczności Wysoka Porta jeszcze raz postanowiła spróbować swoich sił w nadchodzącej kampanii ${ }^{64}$.

Podsumowując powyższe rozważania, należy stwierdzić, że „Pamiętnik Historyczno-Polityczno-Ekonomiczny" w miesięcznych doniesieniach drukował szczegółowe sprawozdania $z$ toczących się działań na froncie wschodnim. Informował o wypadkach rozgrywa-

\footnotetext{
${ }^{62}$ Por. J. Hirtenfeld, op. cit., s. 243-244.

63 PHPE, styczeń 1790, s. 95.

${ }^{64}$ Ibidem, s. 93-96.
} 
jących się na lądzie i - w mniejszym stopniu - na morzu, o stanie i liczebności nieprzyjacielskich wojsk, przytaczał opisy najważniejszych bitew, jak również mało istotnych potyczek. O ile przebieg wojny w początkowej fazie (mimo utraty Oczakowa) był dla Turków dość pomyślny, kampania 1789 r. przynosiła im niepowodzenia. Kilka razy zostali pobici przez Rosjan w otwartym polu, utracili też na ich rzecz twierdze Gałacz, Akerman i wiele znaczace Bendery. Austriacki sojusznik Katarzyny II czynił postępy w Serbii i na Wołoszczyźnie. Szczególnie bolesna dla Porty była utrata Belgradu, znajdującego się pod jej panowaniem od czasu ostatniej wojny z Austrią. Wbrew ogólnemu przekonaniu, jakoby wszelki komentarz odautorski stanowił pogwałcenie dziennikarskiej rzetelności, Świtkowski ujawniał niekiedy własne opinie, zręcznie wplatając je w tekst lub zamieszczając w odnośnikach. Będąc zwolennikiem orientacji protureckiej, $z$ sympatia wypowiadał się na temat Imperium Osmańskiego i Osmanów, chwalił odwage i waleczność żołnierzy tureckich, starał się też sprostować niektóre sądy o tym państwie, uznawane przez siebie za błędne.

\section{Bibliografia}

\section{$\dot{Z}_{\text {RÓDEA DRUKOWANE }}$}

Anthing F., History of the campaigns of Count Alexander Suworow Rymnikski, field-marshal-general in the service of His Imperial Majesty, the Emperor of all the Russias: with a preliminary sketch of his private life and character, vol. II, London 1799.

Erläuterter Plan von der berühmten Schlacht bei Martinjestie in der Wallachey: in welcher unter den Befehlen sr. Durchlaucht des Herzogs Friedrich Josias von Sachsenkoburg, k.k. Generals der Kavallerie (nunmehrigen Feldmarschalls,) und des militärischen Theresienordens Großkreuz, der Großvezier mit 100000 seiner besten Truppen am 22. Sept. 1789 entscheidend geschlagen wurde, Prag 1789.

Hirtenfeld J., Der Militär-Maria-Theresien-Orden und seine Mitglieder: Nach authentischen quellin bearbeitet, Wien 1857.

Lettres à Monsieur le comte de $B^{* * *}$, sur la révolution arrivée en 1789 , sous le règne de Louis XVI, avec des Notes sur les Ministres et autres gens en place qui, depuis le regne de Louis $X V$, ont donné lieu à cette Révolution mémorable, par des déprédations ou des abus d'autorité, ed. par chez les principaux libraires, t. IV, Londres et Paris 1789. 
Oesterreichisches Militär-Konversations-Lexikon. Unter Mitwirkung mehrerer Offiziere der k.k. Armee, redigirt und hrsg. von J. Hirtenfeld, Bd. II (D-G), Wien 1852; Bd. III (H-Kulm), Wien 1852.

Taubmann F., Vita e fatti eroici Barone Gedeone di Laudon, tradotta la prima volta dal tedesco, parte 1, Firenze 1790.

\section{Prasa}

„Gazeta Warszawska” 1788.

„Pamiętnik Historyczno-Polityczno-Ekonomiczny” 1788-1790.

\section{OpRacowania}

Aleksandrowska E., Świtkowski Piotr, [w:] Dawni pisarze polscy od poczatków piśmiennictwa do Młodej Polski. Przewodnik biograficzny i bibliograficzny, t. IV (S-T), koordynacja całości R. Loth, Warszawa 2003, s. 232-233.

Alexander J.T., Catherine the Great. Life and Legend, New York 1989.

Andrusiewicz A., Katarzyna Wielka. Prawda i mit, Warszawa 2012.

Bartoszewicz J., Gazeta księdza Łuskiny, [w:] idem, Znakomici mężowie Polscy $w$ XVIII $w$., t. I, Petersburg 1855, s. 261-330.

Giełżyński W., Prasa warszawska 1661-1914, Warszawa 1962.

Gozdawa-Gołębiowski J., Wojny morskie 1775-1851, Warszawa 2001.

Homola-Dzikowska I., Pamiętnik Historyczno-Polityczny Piotra Świtkowskiego 17821792, Kraków 1960.

Kalinka W., Sejm Czteroletni, t. I, Warszawa 1991.

Karkocha M., Obraz Francji $w$ dobie rewolucji na łamach prasy warszawskiej $z$ lat 1789-1794, Łódź 2011.

Karkocha M., Wojna rosyjsko-turecka na łamach „Pamiętnika Historyczno-Politycznego" (1787-1788), [w:] Sic erat in votis. Europa $i$ swiat w czasach nowożytnych. Studia i szkice ofiarowane Profesorowi Zbigniewowi Anusikowi w sześćdziesiatą rocznicę urodzin, red. M. Karkocha, P. Robak, Łódź 2017, s. 311-342.

Łojek J., Dziennikarze i prasa w Warszawie w XVIII wieku, Warszawa 1960.

Łojek J., „Gazeta Warszawska” księdza Łuskiny (1774-1793), Warszawa 1959.

Łojek J., Historia prasy polskiej, Warszawa 1976.

Łossowska I., Piotr Świtkowski (1744-1793), [w:] Pisarze polskiego Oświecenia, red. T. Kostkiewiczowa, Z. Goliński, t. II, Warszawa 1994, s. 305-319.

Madariaga I. de, Russia in the Age of Catherine the Great, London 1981.

Malleson G.B., Loudon: A Sketch Of The Military Life Of Gideon Ernest, Freiherr Von Loudon, Sometimes Generalissimo Of The Austrian Forces, London 1884.

Montefiore S.S., Katarzyna Wielka i Potiomkin, Warszawa 2013.

Montefiore S.S., Potiomkin, ksiażę książąt, Warszawa 2000.

Morawski W., Szawłowska S., Wojny rosyjsko-tureckie od XVII do XX wieku, Warszawa 2006. 
Roider K.A., Baron Thugut and Austria's response to the French Revolution, Princeton 1987.

Ryniewicz Z., Leksykon bitew świata, Warszawa 2008.

Serczyk W., Katarzyna II carowa Rosji, Wrocław 1989.

Wieczorkiewicz P.P., Historia wojen morskich. Wiek żagla, t. I, Warszawa 1995.

Wurzbach C. von, Biographisches Lexikon des Kaiserthums Oesterreich, T. II, Wien 1857; T. VIII, Wien 1862; T. XI, Wien 1864; T. XIV, Wien 1865; T. XVI, Wien 1867; T. XXI, Wien 1870; T. XXVII, Wien 1874; T. XLV, Wien 1882.

Matgorzata Karkocha

\section{The Russo-Turkish war (the campaign of 1789) in the light of reports from „Pamiętnik Historyczno- -Polityczno-Ekonomiczny"}

$\mathrm{T}$ he subject of the article is the Russo-Turkish war of 1787-1792, more precisely the campaign of 1789 . The issue will be discussed basing on the information published in „Pamiętnik Historyczno-Polityczno-Ekonomiczny”. The journal was coming out in Warsaw in the years 1782-1792, and Piotr Switkowski was its editor and publisher. Since the beginning of the Russo-Turkish war, which Austria joined as Catherine II's ally in February 1788, „Pamiętnik” was posting periodic reports on the activities at the Turkish front. It described the most important battles as well as less significant skirmishes, informed on the movements and the status of the fighting armies, printed the war complements and biographical notes of military commanders. As a supporter of pro-Turkish politics, Switkowski spoke of the Ottoman Porte and inhabitants of Turkey with fondness, praised the bravery of a Turkish soldier, and positively reflected on the military reforms in that country.

Keywords: Russo-Turkish war 1787-1792, campaign of 1789, „Pamiętnik Historyczno-Polityczno-Ekonomiczny", Piotr Switkowski, Warsaw press, $18^{\text {th }}$ century. 